\title{
Breast Milk Management in the Efforts to Reduce Bilirubin Levels in Neonatal Jaundice
}

\author{
Firdaus Firdaus $^{1 *}$ (D), Siti Nur Hasina ${ }^{1}(\mathbb{D})$, Yunik Windarti ${ }^{2}$ D, Devyana Dyah Wulandari ${ }^{3}$ \\ ${ }^{1}$ Department of Nursing, Faculty of Nursing and Midwifery, Universitas Nahdlatul Ulama Surabaya, Surabaya, East \\ Java, Indonesia; ${ }^{2}$ Department of Midwifery, Faculty of Nursing and Midwifery, Universitas Nahdlatul Ulama Surabaya, Surabaya, \\ East Java, Indonesia; ${ }^{3}$ Study Program D4 Health Analyst, Faculty of Health, Universitas Nahdlatul Ulama Surabaya, East Java, \\ Indonesia
}

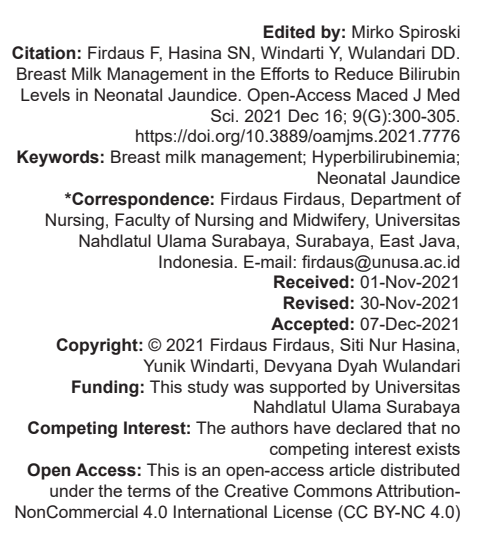

\section{Introduction}

One of the causes of mortality in newborns is bilirubin encephalopathy (better known as kernicterus). Bilirubin encephalopathy is the most severe complication of neonatal jaundice [1]. Jaundice is a condition of newborns low birth weight (LBW) in which the total serum bilirubin level is more than $10 \mathrm{mg} \%$ in the $1^{\text {st }}$ week characterized by yellow discoloration of the skin, conjunctiva, and mucosa, known as pathological jaundice or hyperbilirubinemia [2]. The condition of severe neonatal jaundice often needs to be treated with phototherapy, either in the clinic or in the hospital. During a phototherapy session, the baby is under a special light for a day or 2. One of the phenomena that occur in hospitals is that there is no joint care between mother and baby who undergo phototherapy so that the use of lactation aids to provide a mixture of breast milk and formula milk is a method used to not interfere with the breastfeeding process between mother and child as long as they are not hospitalized [3], [4], [5]. Hyperbilirubinemia is one of several causes of infant mortality in Indonesia which can cause morbidity, disability, and neonatal death. The incidence of hyperbilirubinemia in newborns is caused by several factors including breastfeeding, ABO incompatibility, type of delivery, LBW, and gestational age [6].

It is estimated that, worldwide, severe hyperbilirubinemia affects at least 481,000 term or nearly yearly newborns, of whom 114,000 die and more than 63,000 survive with moderate or severe disability [7]. In Indonesia, the incidence of neonatal jaundice in term infants in several hospitals, including Dr. Sucipto Mangunkusumo Hospital, Dr. Sardjito Hospital, Dr. Soetomo Hospital, and Dr. Kariadi Hospital, varied from $13.7 \%$ to $18.5 \%$. One of the causes of mortality in newborns is bilirubin encephalopathy (better known as kernicterus), which accounts for $6 \%$ of all infant mortality rates [8].

Based on the previous studies, the average decrease in bilirubin levels of infants who were breastfed every $2 \mathrm{~h}$ was $7.17 \mathrm{mg} / \mathrm{dl}$. In infants who are breastfed every $3 \mathrm{~h}$, the average decrease in infant bilirubin levels is $7.01 \mathrm{mg} / \mathrm{dl}$. This shows that breastfeeding every $2 \mathrm{~h}$ is effective in reducing bilirubin levels in infants 
with hyperbilirubinemia with $p=0.000$ [9]. There is a relationship between breastfeeding and the incidence of jaundice in newborns 0-7 days and infants who are exclusively breastfed are better able to deal with the effects of jaundice (jaundice) and can shorten the duration of phototherapy [5], [10]. Inappropriate breastfeeding is associated with an increased incidence of hyperbilirubinemia. Breastfeeding is the best choice given by mothers for their babies [11]. Early breastfeeding has an important role to reduce the occurrence of jaundice, where jaundice is a change in the skin or other organs due to accumulation of bilirubin levels in the blood and will experience an increase in bilirubin levels in the blood called hyperbilirubinemia so that there is a significant relationship between breastfeeding and the incidence of jaundice in babies with hyperbilirubinemia [12], [13], [14].

Hyperbilirubinemia is one of the most common emergencies in newborns. As many as, $25-50 \%$ occur hyperbilirubinemia in term infants and $80 \%$ in infants with LBW. Hyperbilirubinemia is an early diagnosis before kernicterus occurs. Hyperbilirubinemia is bilirubin levels that can cause pathological effects. To control bilirubin levels in newborns, breastfeeding can be done as early as possible [9]. If there is no food in the baby's intestines, direct bilirubin will be converted by enzymes in the intestine into indirect bilirubin which will be reabsorbed in the intestine into the bloodstream. This bilirubin will be bound by albumin and returned to the liver. Adequate breastfeeding will increase intestinal motility and cause bacteria to be introduced into the intestine. These bacteria are able to convert direct bilirubin into urobilin which cannot be reabsorbed so that bilirubin levels will decrease, when bilirubin decreases the degree of jaundice will decrease [15]. Expressing breast milk with the addition of sugar water in the hope of reducing bilirubin levels has proven ineffective; it can even worsen jaundice, because the baby's stomach is full of glucose solutions and makes the baby suckle less frequently so that the bilirubin is delayed out of the baby's body [16].

Management of hyperbilirubinemia aims to prevent indirect bilirubin levels in the blood from reaching neurotoxic levels. Management of hyperbilirubinemia including prevention with breastfeeding, phototherapy, and exchange transfusion. Phototherapy in patients with neonataljaundice is an effectivemeasuretopreventserum total bilirubin levels from increasing. There are clinical trials that have validated the efficacy of phototherapy in reducing excessive unconjugated hyperbilirubinemia, and its implementation has drastically limited the use of exchange transfusion [17], [18]. Infants who were exclusively breastfed during phototherapy required hospitalization less than those who were fed formula milk [19]. Total serum bilirubin level $>5 \mathrm{mg} / \mathrm{dL}$ ( $86 \mathrm{~mol} / \mathrm{L}$ ) is called hyperbilirubinemia. Hyperbilirubinemia is generally normal, only $10 \%$ of which are potentially pathological (bilirubin encephalopathy). Hyperbilirubinemia that leads to pathological conditions include: (1) Present at birth or on the $1^{\text {st }}$ day of life, (2) rapid increase in bilirubin levels (> $5 \mathrm{mg} / \mathrm{dL} / \mathrm{day}$ ), (3) premature babies, (4) jaundice persists at 2 weeks of age or older, and (5) an increase in direct bilirubin $>2 \mathrm{mg} / \mathrm{d}$ or $>20 \%$ of serum total bilirubin. Excessive fear in facing the hyperbilirubinemia can lead to unexpected things, such as increased maternal anxiety, decreased breastfeeding activities, unnecessary therapy, and excessive costs. Therefore, the management of hyperbilirubinemia must be appropriate and effective [13], [20].

Lactation management interventions in mothers can overcome the lack of availability of breast milk and the willingness of mothers to exclusively breastfeed their babies with the diagnosis of neonatal jaundice. As is known, the ingredients contained in breast milk, namely, beta-glucuronidase, will break down bilirubin into a fat-soluble form so that indirect bilirubin will increase and then be reabsorbed by the intestine [21]. Based on the description above, the researchers examined the comparison of phototherapy interventions by maximizing exclusive breastfeeding management with only those who received phototherapy as a solution in the management of neonatal jaundice nursing problems.

\section{Methods}

The design of this study used a quasiexperimental with a pre-test and post-test design with a control group. This research was conducted for 4 months from April to July 2021 at the Ahmad Yani Islamic Hospital, Surabaya. The population in this study was all neonates who received phototherapy and experienced hyperbilirubinemia. Sampling was done by consecutive sampling with inclusion criteria: Infants aged 24 h-28 days, the patient's parents agreed and were able to provide exclusive breastfeeding every $2 \mathrm{~h}$ in patients with phototherapy treatment period, were willing to breastfeed until the end of the study, and had a bilirubin level of $10 \mathrm{mg} / \mathrm{dl}$, and infants without comorbidities and exclusion criteria: Infants with a body weight of $<1000 \mathrm{~g}$, hyperbilirubinemia patients who were at home without treatment, neonates who experienced severe dyspnea and comorbidities, and parents who were not willing to participate in this study were excluded from the study. The total respondents in this study were 52 with the division of 26 intervention groups and 26 control groups.

Data collection in this study was in the form of questionnaires and observation sheets. The questionnaire contained demographic data that were tested by Chi-square (age, gender, length of stay, history of childbirth with risk factors, and Apgar score data). The observation sheet contains the total bilirubin value. Data analysis was carried out on the variable bilirubin levels as the dependent variable and breast milk management as the independent variable. Data analysis was carried out 
by univariate analysis and bivariate analysis. Bivariate analysis using paired sample t-test and independent sample t-test to compare the intervention group that received phototherapy with additional treatment in the form of education of breast milk management and directed to breastfeed a maximum of every $2 \mathrm{~h}$, taught how to store breast milk, and strictly monitoring the breastfeeding to the baby so could get the maximum results and motivate the mother to eat a healthy and balanced diet so that more milk can be produced, of course with the support of the husband. The control group only used treatment in the form of phototherapy and drank milk as usual. Infants with neonatal jaundice were measured for bilirubin levels on the $1^{\text {st }}$ day in the intervention group and the control group. After 3 days of treatment, the baby's bilirubin level was measured simultaneously in the intervention group and the control group.

\section{Results}

The results of this research are as follows:

Table 1 shows that the characteristics of the respondents in this study by gender showed that most $(57.7 \%)$ of the respondents in the intervention group were female, while the majority $(69.0 \%)$ of the control group respondents were female. Characteristics of respondents according to risk factors during delivery, the

Table 1: Respondent characteristics $(n=52)$

\begin{tabular}{|c|c|c|c|c|}
\hline \multirow[t]{3}{*}{ Respondent characteristics } & \multicolumn{4}{|l|}{ Group } \\
\hline & \multicolumn{2}{|c|}{$\begin{array}{l}\text { Intervention group } \\
(n=26)\end{array}$} & \multicolumn{2}{|c|}{$\begin{array}{l}\text { Control group } \\
(n=26)\end{array}$} \\
\hline & $\mathrm{F}$ & $\%$ & $F$ & $\%$ \\
\hline \multicolumn{5}{|l|}{ Gender } \\
\hline Male & 11 & 42.3 & 8 & 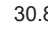 \\
\hline Female & 15 & 57.7 & 18 & 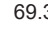 \\
\hline $\mathrm{p}$-value & 0.388 & & & \\
\hline \multicolumn{5}{|l|}{ Apgar score } \\
\hline 5 & 1 & 3.8 & 12 & 46.2 \\
\hline 6 & 4 & 15.4 & 6 & 23. \\
\hline 7 & 8 & 30.8 & 3 & 11.5 \\
\hline 8 & 13 & 50 & 5 & 19.2 \\
\hline $\mathrm{p}$-value & 0.007 & & & \\
\hline \multicolumn{5}{|l|}{ Risk factor } \\
\hline Premature rupture of membranes & 5 & 19.2 & 5 & 19.2 \\
\hline Clear water & 10 & 38.5 & 3 & 11.5 \\
\hline Meconium amniotic fluid & 11 & 42.3 & 18 & 69.3 \\
\hline $\mathrm{p}$-value & 0.065 & & & \\
\hline \multicolumn{5}{|l|}{ Breastfeeding } \\
\hline Breast milk & 0 & 0 & 2 & 7.7 \\
\hline Breast milk and formula milk & 10 & 38.5 & 7 & 26. \\
\hline Formula milk & 16 & 61.5 & 17 & 65.4 \\
\hline $\mathrm{p}$-value & 0.278 & & & \\
\hline \multicolumn{5}{|l|}{ Length of treatment } \\
\hline 2 & 5 & 19.2 & 1 & 3.8 \\
\hline 3 & 10 & 38.5 & 2 & 7.7 \\
\hline 4 & 9 & 34.7 & 3 & 11.6 \\
\hline 5 & 0 & 0 & 7 & 27 \\
\hline 6 & 0 & 0 & 7 & 27 \\
\hline 7 & 1 & 3.8 & 1 & 3.8 \\
\hline 8 & 0 & 0 & 1 & 3.8 \\
\hline 11 & 0 & 0 & 1 & 3.8 \\
\hline 12 & 1 & 3.8 & 1 & 3.8 \\
\hline 14 & 0 & 0 & 1 & 3.8 \\
\hline 16 & 0 & 0 & 1 & 3.8 \\
\hline$p$-value & 0.000 & & & \\
\hline \multicolumn{5}{|l|}{ Weight } \\
\hline SD & 563.2 & & & \\
\hline Mean & 2873 & & & \\
\hline Minimum & 1770 & & & \\
\hline Maximum & 4029 & & & \\
\hline
\end{tabular}

results were almost as stable as $42.3 \%$ of respondents in the intervention group during labor with meconium membranes, while in the control group, most $(69.3 \%)$ labor with meconium membranes. The length of care for infants with the intervention was almost half (38.5) treated for 3 days, and in the control group, the length of treatment was almost half $(27 \%)$ for 5 and 6 days. History of breastfeeding, most respondents in the intervention group $(61.5 \%)$ gave formula milk and in the control group most $(65.4 \%)$ gave formula milk to their babies. The average baby weight is $2873 \mathrm{~g}$.

Table 2 shows that the average total bilirubin level in the intervention group is 13.42 and in the control group is 13.29 , it is obtained $p=0.804$, which means that there is no difference in the average level of anxiety of bilirubin levels in the intervention group and the control group before being given the intervention.

Table 2: Total bilirubin levels before breastfeeding management interventions are given

\begin{tabular}{lllllll}
\hline Groups & Mean & SD & Min & Max & SE & p-value \\
\hline Intervention & 13.42 & 1.943 & 10.94 & 18.18 & 0.381 & 0.804 \\
Control & 13.29 & 1.796 & 18.18 & 17.86 & 0.352 & \\
\hline
\end{tabular}

Table 3 shows that the average total bilirubin level in the intervention group is 7.11 and in the control group 11.58, it is obtained $p=0.000$, which means that there is a difference in the average bilirubin level in the intervention group and the control group after being given the intervention.

Table 3: Total bilirubin levels after breastfeeding management interventions

\begin{tabular}{lllllll}
\hline Groups & Mean & SD & Min & Max & SE & p-value \\
\hline Intervention & 7.11 & 2.346 & 4.8 & 12 & 0.460 & 0.000 \\
Control & 11.58 & 2.096 & 8.67 & 15.44 & 0.411 & \\
\hline
\end{tabular}

Based on Table 4, the results of the independent t-test statistical test obtained $p=0.000$ in the intervention group and $p=0.000$ in the control group, $p<0.05$, it can be concluded that there is a significant change in total bilirubin levels before and after given the mindfulness meditation intervention based on spiritual care to the intervention group and the control group.

Table 4: Bilirubin levels (pre-test and post-test) in the intervention group and control group $(n=26 ; n=26)$

\begin{tabular}{lllll}
\hline Groups & Mean & SD & $\mathrm{t}$ & Significant \\
\hline Intervention & 13.42 & 1.943 & 10.7 & 0.000 \\
$\quad \begin{array}{llll}\text { Pre } \\
\text { Post }\end{array}$ & 7.11 & 2.346 & & \\
Control & & & & \\
$\quad$ Pre & 13.29 & 1.796 & 6.172 & 0.000 \\
Post & 11.58 & 1.792 & & \\
\hline
\end{tabular}

\section{Discussion}

Based on Table 2, the average total bilirubin level before being given breastfeeding management 
education and phototherapy in the intervention group was 13.42 and in the control group was 13.29 with $p=0.804$. There was no average difference between the intervention group and the control group. After the intervention, there was a change in the value of total bilirubin, namely, the average total bilirubin level in the intervention group was 7.11 and in the control group 11.58, $p=0.000$, which means that there was an average difference in the anxiety levels of the rate of bilirubin in the intervention group and the control group after being given intervention. The relationship between breastfeeding and the incidence of neonatal jaundice at the Sumberglagah Hospital Mojokerto found that there was a relationship between breastfeeding and the incidence of physiological jaundice $(63.3 \%)$ with the frequency of breastfeeding $<8$ times $(53.2 \%)$ with $p$-value $=0.003$. It was found that there was a relationship between breastfeeding and the incidence of jaundice [22]. Breastfeeding more than 8 times a day can reduce the amount of bilirubin in the baby's blood, which decreases a lot as colostrum is given which can overcome jaundice, as long as the baby is breastfed as often as possible and not given a breast milk substitute [23].

Based on the previous research that the frequency of breastfeeding with the incidence of jaundice was obtained $(50.2 \%)$ experienced jaundice with the frequency of breastfeeding $<8$ times a day, meaning that the frequency of breastfeeding was a protective factor against the incidence of jaundice so that the frequency of breastfeeding was closely related to the incidence of physiological jaundice. Because breast milk is the staple food for newborns [5]. Semen Padang Hospital is an international standard private hospital that has a neonatology unit. A preliminary study conducted at the neonatology unit of Semen Padang Hospital, it was found that jaundice was the highest case of several diseases experienced by newborns, in 2016, as many as 120 babies experienced physiological jaundice. Physiological jaundice is included in the four major cases, with most cases found [24], [25].

Jaundice is a common condition among neonates, caused by a combination of increased heme and physiologic immaturity of the liver in conjugation and excretion of bilirubin. Meanwhile, according to Kosim et al. (2016), neonatal jaundice is a clinical condition in infants characterized by jaundice staining the skin and sclera due to excessive accumulation of unconjugated bilirubin. The high degree of jaundice in infants is caused by several problems encountered in this study, including the provision of nutrition to infants who provide a mixture of breast milk and formula, the busyness of mothers who mostly work, and there are still many mothers who have just had their first child. Mother's understanding of the procedures for caring for the baby at the time after the birth of the baby and the lack of information about reducing the risk of jaundice in the baby. In this study, it was found that from 52 respondents, there were two babies who had bilirubin with exclusive breastfeeding.

Hyperbilirubinemia associated with breastfeeding can include breastfeeding jaundice (BFJ) and breast milk jaundice (BMJ). Babies who are exclusively breastfed can develop hyperbilirubinemia, known as BFJ. The cause of BFJ is a lack of breast milk intake and usually occurs on the $2^{\text {nd }}$ or $3^{\text {rd }}$ day when there is not much milk. BFJ does not require treatment and there is no need to give water or sugar water. Healthy term babies have fluid and energy reserves that can maintain their metabolism for $72 \mathrm{~h}$. Adequate breastfeeding can overcome BFJ. Mothers should give their babies more opportunities to breastfeed. Colostrum will quickly come out with the baby's continuous sucking. Breast milk will come out faster with early initiation of breastfeeding and hospitalization. BMJ has a characteristic indirect bilirubin level that is still elevated after the first 4-7 days. This condition lasts longer than physiologic hyperbilirubinemia and can last 3-12 weeks without another cause of hyperbilirubinemia found. The cause of BMJ is related to breastfeeding from a certain mother and will usually occur in every baby she breastfeeds. It all depends on the baby's ability to conjugate indirect bilirubin (premature babies will have more severe jaundice) [13], [26], [27].

In general, the cause of neonatal jaundice is an increase in hemolytic disease, but many newborns also become jaundiced because of incomplete bilirubin metabolism which will lead to hyperbilirubinemia [28], [29]. Hyperbilirubinemia is a condition of increased levels of bilirubin in the blood $>5 \mathrm{mg} / \mathrm{dL}$, clinically characterized by the presence of jaundice, with physiological and non-physiological causes [30]. Clinical bilirubin monitoring is the first step so that further interventions can be carried out, whether there is an indication that the baby is undergoing phototherapy or not. This method is considered easier and cheaper for early detection of phototherapy [28]. Basically unconjugated bilirubin is neurotoxic and can cause kernicterus if unconjugated bilirubin levels are more than normal. In addition, hyperbilirubinemia can cause cerebral palsy and sensor neural deafness [31].

This effectiveness includes the frequency, duration, and correct breastfeeding procedures. Breastfeeding for infants is recommended every $2-3 \mathrm{~h}$ or 8-12 times a day for the first few days because decreased calorie intake can cause dehydration and can cause jaundice [9]. In this study, breast milk was given every $2 \mathrm{~h}$ even many of the mothers gave it $<2 \mathrm{~h}$ and had high motivation to go home from the hospital immediately. The ability to swallow and digest breast milk in term newborns is still limited, stomach capacity is also very limited, $<30 \mathrm{cc}$ for term newborns. However, gastric emptying is $2.5-3 \mathrm{~h}$, which is why babies need breast milk as often as possible. When food enters the stomach, there is a rapid peristalsis. This means feeding is followed by a gastric emptying 
reflex. Infants are breastfed 8-10 times a day or at least 2-3 times a day. Infants are fed breast milk substitutes with formula milk 4-6 times a day, but tend to become constipated. Breastfeeding immediately after the baby is born can help the baby in overcoming gastrointestinal problems [32], [33].

\section{Conclusions}

Good lactation management will have a big effect on the acceleration of the decrease in bilirubin levels in infants with phototherapy therapy. Hence, it is necessary to motivate parents, especially mothers, in exclusive breastfeeding without adding formula milk so that the length of care for babies with neonatal icterus is faster.

\section{Acknowledgment}

Our research team would like to thank Universitas Nahdlatul Ulama Surabaya for providing the motivation and funding assistance in this study.

\section{References}

1. Gartner L. Breastfeeding and jaundice. J Perinatol 2002;21(1):S25-9. https://doi.org/10.1038/sj.jp.7210629

2. Lavanya KR, Jaiswai A, Reddy P, Murki S. Predictors of significant jaundice in late preterm infants. Indian Pediatr. 2011;49:717-20. https://doi.org/10.1007/s13312-012-0163-9 PMid:22791669

3. Leung AK, Sauve RS. Breast is best for babies. J Natl Med Assoc. 2005;97(7):1010-19.

PMid:16080672

4. Qamariah N, Andaruni R, Alasiry E. Pengaruh pijat bayi dan breastfeeding terhadap penurun kadar bilirubin pada neonatus dengan hiperbilirubinemia. J IImiah Bidan. 2018;3(2):45.

5. Khairunnisak K, Rosmawar C. Hubungan Pemberian Asi dengan kejadian Ikterus Pada Bayi Baru Lahir 0-7 Hari Di Rumah Sakit Umum Daerah dr. Zainoel abidin Banda Aceh. Skripsi STIKES U'budiyah; 2013.

6. Maulida LF. Ikterus neonatorum. Profesi. 2014;10(26):39-43. Available from: https://www.ejournal.stikespku.ac.id/index.php/ mpp/article/viewFile/63/54. [Last accessed on 2021 Jul 25]

7. Wu RH, Feng S, Han M, Caldwell P, Liu SG, Zhang J, et al. Yinzhihuang oral liquid combined with phototherapy for neonatal jaundice: A systematic review and meta-analysis of randomized clinical trials. BMC Complement Altern Med 2018;18:228. https://doi.org/10.1186/s12906-018-2290-x PMid:30055615

8. Surya Dewi AK, Kardana IM, Suarta K. Efektivitas fototerapi terhadap penurunan kadar bilirubin total pada hiperbilirubinemia neonatal di RSUP Sanglah. Sari Pediatri. 2016;18(2):6. https:// doi.org/10.14238/sp18.2.2016.81-6

9. Indanah I, Karyati S, Yusminah Y. Efektifitas Pemberian AS terhadap Penurunan Kadar Bilirubin. The $10^{\text {th }}$ University Research Colloqium. Indonesia: Sekolah Tinggi IImu Kesehatan Muhammadiyah Gombong; 2019.

10. Lauer BJ, Spector ND. Hyperbilirubinemia in the newborn Pediatr Rev. 2011;32(8):341-9. https://doi.org/10.1542/ pir.32-8-341 PMid:21807875

11. Lin YY, Tsao PN, Hsieh WS, Chen CY, Chou HC. The impact of breast-feeding on early neonatal jaundice. Clin Neonatol. 2008;15:31-5.

12. Wolkoff AW. Hiperbilirubinemia, Harrison Gastroenterologi and Hepatologi. Jakarta: Penerbit EGC; 2014. p. 307-9.

13. Porter ML, Dennis BL. Hyperbilirubinemia in the term newborn. Am Fam Physician 2002;65:599-606.

\section{PMid:11871676}

14. Ullah S, Rahman K, Hedayati M. Hyperbilirubinemia in neonates: Types, causes, clinical examinations, preventive measures and treatments: A narrative review article. Iran J Public Health. 2016;45(5):558-68. PMid:27398328

15. Yuliawati F, Sudiwati NL. Studi komparatif kadar bilirubin pada bayi baru lahir dengan fototerapi yang diberikan ASI esklusif dan non esklusif di RST Malang. Nurs News 2018;3(1):513-25.

16. Preer GL, Philipp BL. Understanding and managing breast milk jaundice. Arch Dis Childhood Fetal Neonatal ED. 2011;96(6):F461-6. https://doi.org/10.1136/adc.2010.184416 PMid:20688866

17. Woodgate $P$, Jardine L. Neonatal jaundice: Phototherapy. BMJ Clin Evid. 2015;2015:0319. PMid:25998618

18. Raghavan $\mathrm{K}$, Thomas $\mathrm{E}$, Patole $\mathrm{S}$, Muller $\mathrm{R}$. Is phototherapy a risk factor for ileus in high-risk neonates? J Matern Fetal Neonat Med. 2005;18:129-31. https://doi.org/10.1080/14767050500233076 PMid:16203599

19. Rahmah R, Yetti $\mathrm{K}$, Besral B. Pemberian ASI efektif mempersingkat durasi pemberian fototerapi. J Keperawatan Indones. 2012;15(1):39-46.

20. Olusanya BO, Osibanjo FB, Slusher TM. Risk factors for severe neonatal hyperbilirubinemia in low and middle-income countries: A systematic review and meta-analysis. PLoS One. 2015;10(2):e0117229. https://doi.org/10.1371/journal. pone. 0117229

PMid:25675342

21. Stokowski LA. Fundamentals of phototherapy for neonatal jaundice. Adv Neonatal Care. 2011;11(5):S10-21. https://doi. org/10.1097/ANC.0b013e31822ee62c PMid:221234

22. Rufaida Z. Hubungan Pemberian ASI Dengan Kejadian Ikterus Neonatorum di UPT Rumah Sakit Sumberglagah Mojokerto, Tesis. Indonesia: Universitas Gadjah Mada; 2015. Available from: http://www.etd.repository.ugm.ac.id/penelitian/ detail/84037. [Last accessed on 2021 Jul 25].

23. Bratton S, Cantu RM, Stern M. Breast milk jaundice. In: StatPearls. Treasure Island, FL: StatPearls Publishing; 2021. Available from: https://www.ncbi.nlm.nih.gov/books/NBK537334 [Last accessed on $2021 \mathrm{Feb} 13]$.

24. Apriyulan EM. Hubungan Frekuensi Pemberian Asi Dengan Derajat Ikterus Neonatorum Fisologis Di PKU Muhammadiyah 1 Yogyakarta, Skripsi Thesis. Indonesia: Universitas 'Aisyiyah Yogyakarta; 2017. Available from: http://www.digilib.unisayogya. ac.id/3023/1/NASKAH\%20PU [Last accessed on 23 Sep 2020]. 
25. Budi Artha K. Faktor-faktor yang berhubungan dengan pemberian ASI ekslusif oleh ibu menyusui yang bekerja sebagai tenaga kesehatan. J IImu Kesehatan. 2017;2:159-74.

26. Kosim MS, Soetandio R, Sakundarno M. Dampak lama fototerapi terhadap penurunan kadar bilirubin total pada hiperbilirubinemia neonatal. Sari Pediatri. 2008;10(3). https://doi.org/10.14238/ sp10.3.2008.201-6

27. Ikatan Dokter Anak Indonesia. Indikasi Terapi Sinar Pada Bayi Menyusui Yang Kuning; 2013. Available from: https://www.idai. or.id/artikel/klinik/asi/indikasi-terapi-sinar-pada-bayi-menyusuiyang-kuning [Last accessed on 2021 Sep 25].

28. Bhutani V. Phototherapy to prevent severe neonatal hyperbilirubinemia in the newborn infant 35 or more weeks of gestation. J Am Acad Pediatr. 2011;128(4):e1046-52. https:// doi.org/10.1542/peds.2011-1494

PMid:21949150

29. Gowen CW. Kedokteran Fetal dan Neonatal, Nelson IImu
Kesehatan Anak Esensial. Jakarta: Saunders Elsevier; 2011. p. 115-6.

30. Mathindas S, Wilar R, Wahani A. Hiperbilirubinemia pada neonatus. J Biomed. 2013;5(1):S4-10.

31. Gamaleldin R, Iskander I, Seoud I, Aboraya H, Aravkin A, Sampson PD, et al. Risk factors for neurotoxicity in newborns with severe neonatal hyperbilirubinemia. Pediatrics. 2011;128(4):e925-31. https://doi.org/10.1542/peds.2011-0206 PMid:21911352

32. Soldi A, Tonetto P, Varalda A, Bertino E. Neonatal jaundice and human milk. J Matern Fetal Neonatal Med. 2011;24(1):85-7. https://doi.org/10.3109/14767058.2011.607612 PMid:21942599

33. Nandraziova L, Matasova K, Gumulak R. Phototherapy and its effect on some physiological functions in newborns. Acta Med Martiniana. 2018;18:5-13. https://doi.org/10.2478/ acm-2018-0001 